\title{
Uji Aktivitas Antihiperurisemia Ekstrak Etanol Beberapa Tumbuhan Famili Asteraceae
}

\author{
Surya Amal*, Neni Sri Gunarti, Kamal Lullael, Kankan Prama Soebakti, Dinda Gusti Mahdalena, \\ Nida Nur Fadhillah, Himyatul Hidayah
}

\author{
Fakultas Farmasi Universitas Buana Perjuangan Karawang \\ Jl. HS. Ronggowaluyo Sirnabaya, Puseurjaya, Telukjambe Timur, Karawang, \\ Jawa Barat, 41361, Indonesia \\ *E-mail: surya.amal@ubpkarawang.ac.id
}

(Submit 19/12/2021, Revisi 20/12/2021, Diterima 30/12/2021, Terbit 31/12/2021)

\begin{abstract}
Abstrak
Tumbuhan famili Asteraceae sering digunakan masyarakat sebagai obat tradisional. Efek farmakologi tumbuhan Asteraceae dapat dikaitkan dengan berbagai senyawa fitokimia, termasuk polifenol, asam fenolik, flavonoid, asetilena dan triterpen. Flavonoid telah terbukti memiliki aktivitas tinggi untuk penghambatan terhadap xantin oksidase, dan ditemukan memiliki kemampuan untuk menurunkan kadar asam urat dalam serum. Tujuan penelitian ini untuk menguji aktivitas anti hiperurisemia ekstrak etanol beberapa tumbuhan anggota famili Asteraceae (Taraxacum officinale, Crassocephalum crepidioides, Elephantopus scaber, Gynura procumbens, Ageratum conyzoides, Sonchus arvensis, Gynura divaricate) terhadap hewan uji mencit (Mus musculus). Metode penelitian yang digunakan adalah eksperimental dengan menggunakan hewan uji mencit jantan galur Balb/c. Pada penelitian ini kadar asam urat diukur menggunakan metode POCT (Point of Care Testing) dengan alat UA Sure. Hasil penelitian menunjukkan bahwa semua tumbuhan famili Asteraceae yang diuji positif mengandung senyawa flavonoid. Tumbuhan yang memberikan efek antihiperurisemia paling tinggi dalam menurunkan kadar asam urat yaitu ekstrak etanol Tempuyung (Sonchus arvensis) pada dosis $500 \mathrm{mg} / \mathrm{Kg} \mathrm{BB}$ dengan persentase penurunan sebesar $52 \% \pm 0,2$. Sedangkan penurunan paling terkecil pada ekstrak etanol Bandotan (Ageratum conyzoides) pada dosis $500 \mathrm{mg} / \mathrm{KgBB}$ dengan persentase penurunan sebesar $4,80 \% \pm$ 0,01 . Penelitian ini menyimpulkan bahwa ekstrak etanol beberapa tumbuhan famili Asteraceae berpengaruh secara signifikan terhadap penurunan kadar asam urat pada mencit dan memiliki potensi sebagai obat antihiperurisemia.
\end{abstract}

Kata kunci: antihiperurisemia, famili Asteraceae, mencit

\section{Pendahuluan}

Hiperurisemia adalah kondisi di mana terjadi peningkatan kadar asam urat (AU) darah di atas normal. Produksi asam urat yang berlebihan dapat terjadi akibat kelainan pada sistem enzim yang mengatur metabolisme purin (misalnya, peningkatan aktivitas 
phosphoribosyl pyrophosphate [PRPP] sintetase atau defisiensi hypoxanthine-guanine phosphoribosyl transferase [HGPRT]). ${ }^{(1)}$ Tujuan pengobatan hiperurisemia adalah untuk mengurangi total asam urat tubuh dan akibatnya untuk meminimalkan risiko flare akut, artropati, nefrolitiasis dan komplikasi lainnya. ${ }^{(2)}$

Indonesia merupakan wilayah kekayaan biodiversitas dunia terbesar kedua, termasuk kekayaan ragam tumbuhan obat dan ribuan spesies sudah digunakan masyarakat, salah satunya adalah tumbuhan dari famili Asteraceae. Asteraceae adalah famili tumbuhan berbunga terbesar (Angiospermae) yang memiliki jumlah spesies terbanyak dari semua famili tumbuhan, dengan sekitar 24.000 spesies tersebar di 1.620 genus dan 12 subfamili.(3)

Berbagai efek obat dari tumbuhan ini dihubungkan dengan berbagai kandungan metabolit bioaktif sekunder seperti flavonoid, asam fenolik, kumarin, terpenoid (monoterpen, seskuiterpen, diterpen, dan triterpen) dan sterol yang telah sering dilaporkan dari famili Asteraceae. ${ }^{(4,5)}$ Tumbuhan ini memiliki bentuk herba atau semak yang sering terabaikan padahal memiliki potensi sebagai obat, salah satunya untuk mengatasi hiperurisemia yang dihubungkan dengan senyawa flavonoid dalam tumbuhan famili Asteraceae. ${ }^{(6)}$

Berdasarkan hal tersebut telah dilakukan penelitian untuk mengetahui aktivitas antihiperurisemia dari beberapa tumbuhan famili Asteraceae (Taraxacum officinale, Crassocephalum crepidioides, Elephantopus scaber, Gynura procumbens, Ageratum conyzoides, Sonchus arvensis, Gynura divaricate terhadap hewan uji mencit (Mus musculus). Tujuan utama penelitian ini untuk mengevaluasi potensi beberapa tumbuhan famili Asteraceae sebagai obat antihiperurisemia.

\section{Metode}

Penelitian ini dirancang secara eksperimental di Laboratorium Farmasi Universitas Buana Perjuangan Karawang dengan menggunakan rancangan acak lengkap (Completely Randomized Design (CRD)). Hewan uji yang digunakan adalah mencit jantan galur Balb/c dengan umur 2-3 bulan dan berat 20-30 gram yang dikelompokkan secara acak.

Simplisia dari tumbuhan famili Asteraceae (Taraxacum officinale, Crassocephalum crepidioides, Elephantopus scaber, Gynura procumbens, Ageratum conyzoides, Sonchus arvensis, Gynura divaricate) masing-masing diekstraksi dengan metode maserasi dengan menggunakan pelarut etanol 70\%. Ekstrak yang telah didapat diberikan kepada mencit yang telah diinduksi hiperurisemia dengan jus hati ayam dan kalium oksonat, selanjutnya diamati penurunan kadar asam urat mencit. 


\section{Alat}

Alat yang digunakan dalam penelitian ini antara lain rotary evaporator (IKA), neraca digital (Taffware), timbangan hewan (Ohauss), oven (IKA), blender (Phillips), kertas saring, alat tes strip asam urat (Family Dr.), spuit (Disposable Syringe), sonde oral (Gavage), box kandang mencit (Lion Star), bunsen, penjepit kayu, spatula, pipet tetes, rak tabung reaksi dan alat-alat gelas (Iwaky pyrex).

\section{Bahan}

Bahan yang digunakan dalam penelitian ini antara lain simplisia Tempuyung dan Bandotan, pelarut etanol p.a (Merck), CMC-Na (Merck), jus hati ayam, kalium oksonat (Merck), allopurinol (KF), aquadest, tisu, kapas, alumunium foil, $\mathrm{HgCl}_{2}$ p.a (Merk), $\mathrm{KI}$ teknis (Merck), $\mathrm{H}_{2} \mathrm{SO}_{4}$ pekat p.a (Merck), $\mathrm{HCl}$ Pekat p.a (Merck), $\mathrm{CHCl}_{3}$ p.a (Merck), $\mathrm{CH}_{3} \mathrm{COOH}$ glasial (Merck), $\mathrm{FeCl}_{3} 1 \%$ (Merck), serbuk $\mathrm{Mg}, \mathrm{Bi}_{2} \mathrm{O}_{3}$ (Merck), $\mathrm{N}_{2} \mathrm{O}_{5}, \mathrm{H}_{2} \mathrm{O}$, CMC-Na 1\% (Merck), mencit jantan dengan berat rata-rata 20-3- gram dan berumur 2-3 bulan.

\section{Prosedur}

Hewan uji mencit dibagi menjadi 6 (enam) kelompok dimana masing-masing kelompok terdiri dari 3 (tiga) ekor mencit. Dosis yang digunakan pada penelitian ini untuk masing - masing ekstrak etanol tumbuhan yang diuji adalah 100, 300 dan 500 mg/kgBB yang diperoleh dari hasil orientasi.

$\mathrm{KN}$ : Kontrol normal, tidak diberi perlakuan apapun.

K - : Kontrol negatif; diberi pakan standar, jus hati ayam 2 kali sehari selama 12 hari dan kalium oksonat $250 \mathrm{mg} / \mathrm{Kg}$ BB selama 2 kali sehari pada hari ke 7 hingga hari ke 12. CMC-Na 0,5\% selanjutnya diberikan pada hari ke 9 hingga hari ke 12.

$\mathrm{K}+$ : Kontrol positif; diberi pakan standar, jus hati ayam 2 kali sehari selama 12 hari dan kalium oksonat $250 \mathrm{mg} / \mathrm{Kg}$ BB selama 2 kali sehari pada hari ke 7 hingga hari ke 12 . Allopurinol $10 \mathrm{mg} / \mathrm{kg} \mathrm{BB}$ selanjutnya diberikan pada hari ke 9 hingga hari ke 12.

P1 : Pengujian ekstrak etanol tumbuhan uji dengan dosis $100 \mathrm{mg} / \mathrm{kg} \mathrm{BB}$; diberi pakan standar, jus hati ayam 2 kali sehari selama 12 hari dan kalium oksonat $250 \mathrm{mg} / \mathrm{Kg}$ BB selama 2 kali sehari pada hari ke 7 hingga hari ke 12. Ekstrak etanol tumbuhan uji dengan dosis $100 \mathrm{mg} / \mathrm{kg}$ BB per oral selanjutnya diberikan pada hari ke 9 hingga hari ke 12 .

P2 : Pengujian ekstrak etanol tumbuhan uji dengan dosis $300 \mathrm{mg} / \mathrm{kg} \mathrm{BB}$, diberi pakan standar, jus hati ayam 2 kali sehari selama 12 hari dan kalium oksonat $250 \mathrm{mg} / \mathrm{Kg}$ BB selama 2 kali sehari pada hari ke 7 hingga hari ke 12. Ekstrak etanol tumbuhan uji dosis $300 \mathrm{mg} / \mathrm{kg}$ BB per oral selanjutnya diberikan pada hari ke 9 hingga hari ke 12 . 
P3 : Pengujian ekstrak etanol tumbuhan uji dengan dosis $500 \mathrm{mg} / \mathrm{kg} \mathrm{BB}$, diberi pakan standar, jus hati ayam 2 kali sehari selama 12 hari dan kalium oksonat $250 \mathrm{mg} / \mathrm{Kg}$ BB selama 2 kali sehari pada hari ke 7 hingga hari ke 12. Ekstrak etanol tumbuhan uji dosis $500 \mathrm{mg} / \mathrm{kg}$ BB per oral selanjutnya diberikan pada hari ke 9 hingga hari ke 12.

Pengambilan darah mencit dilakukan dengan cara melukai ekor mencit, dan pengujian kadar asam urat dilakukan dengan menggunakan metode POCT (Point of Care Testing) dengan menggunakan alat UA Sure. Selanjutnya dilakukan perhitungan persentase $(\% \mathrm{P})$ kadar asam urat dari data yag telah didapat sebelumnya dengan persamaan:

$$
\% \mathrm{P}=\frac{\text { Kadar }(-)-\text { Kadar } P}{\operatorname{Kadar}(-)} \times 100 \%,
$$

dimana Kadar $(p)=$ kadar asam urat darah kelompok uji dan Kadar $(-)=$ kadar asam urat darah kelompok kontrol negatif. (7)

Analisis data menggunakan program SPSS dengan melihat uji normalitas (ShapiroWilk) dan uji homogenitas (Lavene) yang digunakan sebagai syarat uji analisis varian satu arah ANOVA untuk melihat perbedaan rata-rata dari dua atau lebih kelompok perlakuan dan dilanjutkan dengan uji Beda Nyata Terkecil (BNT). Jika salah satu syarat untuk uji ANOVA tidak dipenuhi, maka dilakukan uji Kruskal-Wallis untuk melihat adanya perbedaan, selanjutnya dilakukan uji MannWhitney. ${ }^{(8)}$

\section{Hasil}

Sampel tanaman diperoleh dari kebun dataran tinggi di Pulau Jawa di bawah pengelolaan Balai Pertanian tanaman Rempah dan Obat Bogor (Balittro) yaitu Taman Kebun Percobaan Jalan Manoko Lembang Bandung. Determinasi tanaman dilakukan di Pusat Penelitian Biologi LIPI Cibinong Bogor. Selanjutnya pemeriksaan ekstrak yang dilakukan pada penelitian ini meliputi uji organoleptik, bobot jenis dan skrining fitokimia. Berdasarkan hasil yang diperoleh (Tabel 1.), uji organoleptik dilakukan dengan tujuan sebagai pengenalan awal esktrak etanol secara objektif berupa bentuk, warna, bau dan rasa. Hasil ini dapat digunakan sebagai dasar untuk menguji ekstrak etanol selama penyimpanan yang dapat mempengaruhi khasiatnya. Hasil organoleptik pada ekstrak etanol tumbuhan famili Asteraceae ini memiliki bentuk kental dengan warna hijau pekat disertai bau khas dan rasa pahit. Untuk parameter nonspesifik ialah bobot jenis, setiap esktrak memiliki nilai yang berbeda-beda. Untuk ekstrak etanol Jombang (Taraxacum officinale) memiliki nilai bobot jenis sebesar $0,88 \mathrm{~g} / \mathrm{mL}$, untuk ekstrak etanol Sintrong (Crassocephalum crepidioides) sebesar 0,86 g/mL, ekstrak etanol Tapak liman (Elephantopus scaber) sebesar 0,9 $\mathrm{g} / \mathrm{mL}$, ekstrak etanol Sambung Nyawa (Gynura procumbens) sebesar $0,86 \mathrm{~g} / \mathrm{mL}$, ekstrak etanol Bandotan (Ageratum conyzoides) sebesar $0,88 \mathrm{~g} / \mathrm{mL}$, ekstrak etanol Tempuyung (Sonchus arvensis) sebesar $0,83 \mathrm{~g} / \mathrm{mL}$, ekstrak etanol Daun Dewa (Gynura divaricate) sebesar 0,85 $\mathrm{g} / \mathrm{mL}$ dan ekstrak etanol Sembung (Bulmea balsamifera) sebesar 0,88 g/mL. 
Tabel 1. Hasil Uji Parameter Spesifik dan Non Spesifik

\begin{tabular}{llllcc}
\hline \multirow{2}{*}{$\begin{array}{c}\text { Nama Ekstrak } \\
\text { Etanol }\end{array}$} & \multicolumn{3}{c}{ Parameter Spesifik } & Parameter Non \\
\cline { 2 - 5 } Jombang & Kentuk & Warna & Rasa & Bau & Bobot Jenis \\
\cline { 2 - 5 } Sintrong & Kental & Hijau pekat & Pahit & Bau khas & $0,88 \mathrm{~g} / \mathrm{mL} \pm 0,006$ \\
& & $\begin{array}{l}\text { Hijau ke } \\
\text { jingga }\end{array}$ & Pahit & Bau khas & $0,86 \mathrm{~g} / \mathrm{mL} \pm 0,006$ \\
Tapak Liman & Kental & Hijau pekat & Pahit & Bau khas & $0,9 \mathrm{~g} / \mathrm{mL} \pm 0,002$ \\
Sambung Nyawa & Kental & Hijau pekat & Pahit & Bau khas & $0,86 \mathrm{~g} / \mathrm{mL} \pm 0,001$ \\
Bandotan & Kental & Hijau pekat & Pahit & Bau khas & $0,88 \mathrm{~g} / \mathrm{mL} \pm 0,005$ \\
Tempuyung & Kental & Hijau pekat & Pahit & Bau khas & $0,83 \mathrm{~g} / \mathrm{mL} \pm 0,001$ \\
Daun Dewa & Kental & Hijau pekat & Pahit & Bau khas & $0,85 \mathrm{~g} / \mathrm{mL} \pm 0,005$ \\
Sembung & Kental & Hijau pekat & Pahit & Bau khas & $0,88 \mathrm{~g} / \mathrm{mL} \pm 0,01$ \\
\hline
\end{tabular}

Hasil skrining fitokimia menunjukkan bahwa pada tumbuhan famili Asteraceae tersebut mengandung flavonoid. Berbagai studi menunjukkan bahwa senyawa-senyawa golongan flavonoid dapat menghambat aktivitas xantin oksidase. Diketahui setidaknya 2 (dua) flavonoid, quercetin dan silibin, menghambat aktivitas xantin oksidase, sehingga mengakibatkan penurunan cedera oksidatif. Jalur xanthine oxidase telah terlibat sebagai rute penting dalam cedera oksidatif jaringan, terutama setelah iskemiareperfusi. Baik xanthine dehydrogenase dan xanthine oxidase terlibat dalam metabolisme xanthine menjadi asam urat. Studi tentang hubungan struktur-fungsi dimana luteolin (3',4'5,7-tetrahydroxyflavone) dilaporkan sebagai inhibitor paling kuat dari xanthine oxidase. ${ }^{(9)}$

Tabel 2. Hasil Uji Skrining Fitokimia

\begin{tabular}{lllllllll}
\hline \multicolumn{1}{c}{ Golongan Senyawa } & A & B & C & D & E & F & G & H \\
\hline Alkaloid & - & + & - & - & + & + & + & + \\
Flavonoid & + & + & + & + & + & + & + & + \\
Tanin & + & - & + & + & + & - & + & - \\
Quinon & + & + & - & - & - & - & + & + \\
Saponin & - & + & + & - & - & - & - & + \\
Triterpen \& Steroid & - & + & + & - & - & - & + & - \\
\hline
\end{tabular}

Keterangan:
A: Ekstrak Jombang
D: Ekstrak Tapak Liman
G: Ektrak Dewa
B: Ekstrak Sintrong
E: Ekstrak Bandotan
$\mathrm{H}$ : Ekstrak
C: Ekstrak Sambung Nyawa
F: Ekstrak Tempuyung
Sembung

\section{Pembahasan}

Hiperurisemia adalah kondisi dimana terjadi peningkatan kadar asam urat (AU) darah di atas normal. Tujuan penelitian ini untuk menguji aktivitas antihiperurisemia ekstrak etanol beberapa tumbuhan anggota famili Asteraceae. Adapun beberapa ekstrak yang digunakan ialah esktrak etanol Jombang (Taraxacum officinale), esktrak etanol Sintrong 
Crassocephalum crepidioides), ekstrak etanol Tapak liman (Elephantopus scaber), ekstrak etanol Sambung Nyawa (Gynura procumbens), ekstrak etanol Bandotan (Ageratum conyzoides), ekstrak etanol Tempuyung (Sonchus arvensis), ekstrak etanol Daun Dewa (Gynura divaricate) dan ekstrak etanol Sembung (Bulmea balsamifera).

Pada penelititian ini hewan percobaan yang digunakan dipuasakan terlebih dahulu selama 18 jam, kemudian diukur kadar asam urat awalnya pada $\mathrm{H}_{0}$ (hari ke-0). Kadar asam urat normal mencit 1,5-3,3 $\mathrm{mg} / \mathrm{dL}$. ${ }^{(10)}$ Pengambilan darah pada $\mathrm{H} 0$ kadar asam urat awal dengan rata-rata $3,0 \mathrm{mg} / \mathrm{dL}$. Setelah pengukuran $\mathrm{H} 0$ hewan uji diinduksikan jus hati ayam dan kalium oksonat $250 \mathrm{mg} / \mathrm{Kg}$ BB selama 12 hari bertujuan untuk meningkatkan hiperurisemia. Pemberian kalium oksonat pada hari ke 7 hingga hari ke 12. Kalium oksonat bekerja dengan menghambat efek enzim urikase memproduksi kadar asam urat secara berlebihan di dalam darah. Jika enzim urikase telah dihambat, maka terjadi peningkatan kadar asam urat sehingga dapat digunakan untuk penginduksian hiperurisemia.

Pengukuran kadar asam urat pada $\mathrm{H}_{12}$ (hari ke 12) untuk menunjukan adanya peningkatan hiperurisemia pada mencit. Pengukuran pada $\mathrm{H}_{12}$ pada kelompok kontrol maupun kelompok percobaan tidak ada perbedaan yang signifikan $(p \geq 0.05)$. Rata-rata kadar asam urat pada $\mathrm{H}_{12}$ setelah penginduksian ialah $6,5 \mathrm{mg} / \mathrm{dL}$. Mencit mengalami hiperurisemia jika kadar asam urat mencapai $6,2-7,1 \mathrm{mg} / \mathrm{dL} .{ }^{(10)}$

Pengukuran kadar asam urat pada $\mathrm{H}_{15}$ (hari ke 15) untuk menunjukan penurunan hiperurisemia pada mencit yang telah diberikan kelompok perlakuan dan kelompok kontrol positif yang diberikan allopurinol $10 \mathrm{mg} / \mathrm{Kg} \mathrm{BB}$, Kelompok kontrol negatif (CMC-Na 0,5\%) dan kelompok percobaan ekstrak. Pengukuran pada $\mathrm{H}_{12}$ (hari ke12) pada kelompok kontrol maupun kelompok percobaan tidak ada perbedaan yang signifikan $(p \geq 0.05$ ). Data pengukuran yang diperoleh selanjutnya dianalisis untuk melihat perbandingan kadar asam urat awal, setelah induksi dan kelompok perlakuan. Hasil rata-rata kadar asam urat awal, setelah induksi dan kelompok perlakuan (Tabel 3).

Berdasarkan persentase penurunan kadar asam urat pada mencit tiap kelompok, penurunan kadar asam urat menunjukan bahwa setiap kelompok percobaan memiliki potensi aktivitas antihiperurisemia terhadap mencit. Pada kelompok kontrol positif dengan allopurinol $10 \mathrm{mg} / \mathrm{Kg} \mathrm{BB}$, dimana penurunan kadar asam urat pada $\mathrm{H}_{12}$ ke $\mathrm{H}_{15}$ dengan kadar setelah induksi $6,9 \mathrm{mg} / \mathrm{dL}$ menjadi $4,4 \mathrm{mg} / \mathrm{dL}$ dengan persentase penurunan $36,23 \%$.

Pada perlakuan kelompok percobaan ekstrak memiliki perbedaan penurunan sehingga persentase penurunan kadar asam urat kelompok percobaan dilakukan perbandingan dengan dosis yang dapat menurunkan lebih besar setiap ekstrak. Perlakuan kelompok ekstrak diberikan setelah $\mathrm{H}_{12}$ hingga $\mathrm{H}_{15}$. 
Tabel 3 Hasil rata-rata kadar asam urat awal, setelah induksi dan kelompok perlakuan

\begin{tabular}{|c|c|c|c|}
\hline \multirow{2}{*}{$\begin{array}{l}\text { Kelompok } \\
\text { Perlakuan }\end{array}$} & \multicolumn{3}{|c|}{ Rata-rata Kadar Asam Urat (mg/dL) } \\
\hline & Hari 0 & Hari 12 & Hari 15 \\
\hline KN & $3,0 \pm 0$ & $3,0 \pm 0$ & $3,0 \pm 0$ \\
\hline K- & $3,0 \pm 0$ & $6,2 \pm 0,15$ & $6,5 \pm 0,26$ \\
\hline K+ & $3,0 \pm 0$ & $6,9 \pm 0,52$ & $4,4 \pm 0,8$ \\
\hline P1a & $3,0 \pm 0$ & $6,9 \pm 0,38$ & $6,1 \pm 0,52$ \\
\hline $\mathbf{P 2 a}$ & $3,0 \pm 0$ & $7,0 \pm 0,38$ & $5,3 \pm 0,59$ \\
\hline P3a & $3,0 \pm 0$ & $7,0 \pm 0,58$ & $4,4 \pm 0,8$ \\
\hline P1b & $3,0 \pm 0$ & $6,7 \pm 0,34$ & $6,5 \pm 0,26$ \\
\hline $\mathbf{P} 2 b$ & $3,0 \pm 0$ & $6,7 \pm 0,5$ & $6,4 \pm 0,6$ \\
\hline P3b & $3,0 \pm 0$ & $6,3 \pm 0,2$ & $5,8 \pm 0,3$ \\
\hline P1c & $3,0 \pm 0$ & $6,2 \pm 0,15$ & $5,5 \pm 0,3$ \\
\hline P2c & $3,0 \pm 0$ & $6,9 \pm 0,15$ & $5,2 \pm 0,44$ \\
\hline P3c & $3,0 \pm 0$ & $7,3 \pm 0,06$ & $4,9 \pm 0,25$ \\
\hline P1d & $3,0 \pm 0$ & $6,4 \pm 0,1$ & $5,7 \pm 0,25$ \\
\hline P2d & $3,0 \pm 0$ & $6,3 \pm 0,15$ & $5,3 \pm 0,17$ \\
\hline P3d & $3,0 \pm 0$ & $6,4 \pm 0,1$ & $5,8 \pm 0,14$ \\
\hline P1e & $3,0 \pm 0$ & $6,2 \pm 0,29$ & $6,0 \pm 0,25$ \\
\hline $\mathrm{P} 2 \mathrm{e}$ & $3,0 \pm 0$ & $6,4 \pm 0,15$ & $6,1 \pm 0,17$ \\
\hline P3e & $3,0 \pm 0$ & $6,6 \pm 0,55$ & $6,0 \pm 0,25$ \\
\hline P1f & $3,0 \pm 0$ & $6,2 \pm 0,32$ & $5,4 \pm 0,4$ \\
\hline P2f & $3,0 \pm 0$ & $6,7 \pm 0,38$ & $4,7 \pm 0,15$ \\
\hline P3f & $3,0 \pm 0$ & $6,2 \pm 0,17$ & $5,4 \pm 0,25$ \\
\hline P1g & $3,0 \pm 0$ & $6,2 \pm 0,20$ & $5,7 \pm 0,25$ \\
\hline P2g & $3,0 \pm 0$ & $7,2 \pm 0,45$ & $6,7 \pm 0,45$ \\
\hline P3g & $3,0 \pm 0$ & $6,7 \pm 0,35$ & $5,1 \pm 0,20$ \\
\hline P1h & $3,0 \pm 0$ & $6,2 \pm 0,20$ & $5,7 \pm 0,25$ \\
\hline P2h & $3,0 \pm 0$ & $6,6 \pm 0,41$ & $5,8 \pm 0,26$ \\
\hline P3h & $3,0 \pm 0$ & $7,3 \pm 0,20$ & $5,1 \pm 0,55$ \\
\hline
\end{tabular}

Keterangan Tebel 3:

$\begin{array}{ll}\text { KN } & \text { : Kontrol Normal } \\ \text { K- } & \text { : Kontrol Negatif } \\ \text { K+ } & \text { : Kontrol Positif } \\ \text { P1a } & \text { : Ekstrak Jombang 100mg } \\ \text { P2a } & \text { : Ekstrak Jombang 300mg } \\ \text { P3a } & \text { : Ekstrak Jombang 500mg } \\ \text { P1b } & \text { : Ekstrak Sintrong 100mg } \\ \text { P2b } & \text { : Ekstrak Sintrong 300mg } \\ \text { P3b } & \text { : Ekstrak Sintrong 500mg } \\ \text { P1c } & \text { : Ekstrak Sambung Nyawa 100mg } \\ \text { P2c } & \text { : Ekstrak Sambung Nyawa 300mg } \\ \text { P3c } & \text { : Ekstrak Sambung Nyawa 500mg } \\ \text { P1d } & \text { : Ekstrak Tapak Liman 100mg } \\ \text { P2d } & \text { : Ekstrak Tapak Liman 300mg }\end{array}$

P3d : Ekstrak Tapak Liman 500mg

P1e : Ekstrak Bandotan 100mg

P2e : Ekstrak Bandotan 300mg

P3e : Ekstrak Bandotan 500mg

P1f : Ekstrak Tempuyung 100mg

P2f : Ekstrak Tempuyung 300mg

P3f : Ekstrak Tempuyung 500mg

P1g : Ekstrak Daun Dewa 100mg

P2g : Ekstrak Daun Dewa 300mg

P3g : Ekstrak Daun Dewa 500mg

P1h : Ekstrak Sembung 100mg

P2h : Ekstrak Sembung 300mg

P3h : Ekstrak Sembung 500mg 
Kelompok percobaan bertujuan untuk mengetahui penurunan kadar asam urat pada hewan uji dengan dibandingkan allopurinol sebagai obat antihiperurisemia. Diperoleh kadar asam urat pada kelompok percobaan ekstrak etanol Jombang (Taraxacum officinale) dosis $500 \mathrm{mg}$ dengan kadar setelah diinduksi 7,0 mg/dL menjadi 4,4 $\mathrm{mg} / \mathrm{dL}$ dengan persentase penurunan $37,14 \%$. Kadar asam urat pada kelompok percobaan ekstrak etanol Sintrong (Crassocephalum crepidioides) dosis $500 \mathrm{mg}$ dengan kadar setelah diinduksi $6,3 \mathrm{mg} / \mathrm{dL}$ menjadi $5,8 \mathrm{mg} / \mathrm{dL}$ dengan persentase penurunan $7,93 \%$. Kadar asam urat pada kelompok percobaan ekstrak etanol Tapak Liman (Elephantopus scaber) dosis $500 \mathrm{mg}$ dengan kadar setelah diinduksi 7,3 $\mathrm{mg} / \mathrm{dL}$ menjadi $4,9 \mathrm{mg} / \mathrm{dL}$ dengan persentase penurunan $37 \%$. Kadar asam urat pada kelompok percobaan ekstrak etanol Sambung Nyawa (Gynura procumbens) dosis $300 \mathrm{mg}$ dengan kadar setelah diinduksi $6,3 \mathrm{mg} / \mathrm{dL}$ menjadi $5,3 \mathrm{mg} / \mathrm{dL}$ dengan persentase penurunan $17,46 \%$. Kadar asam urat pada kelompok percobaan ekstrak etanol Bandotan (Ageratum conyzoides) dosis $500 \mathrm{mg}$ dengan kadar setelah diinduksi $6,6 \mathrm{mg} / \mathrm{dL}$ menjadi $6,0 \mathrm{mg} / \mathrm{dL}$ dengan persentase penurunan $4,80 \%$. Kadar asam urat pada kelompok percobaan ekstrak etanol Tempuyung (Sonchus arvensis) dosis $500 \mathrm{mg}$ dengan kadar setelah diinduksi $6,2 \mathrm{mg} / \mathrm{dL}$ menjadi $5,4 \mathrm{mg} / \mathrm{dL}$ dengan persentase penurunan $52 \%$. Kadar asam urat pada kelompok percobaan ekstrak etanol Daun Dewa (Gynura divaricate) dosis 500 mg dengan kadar setelah diinduksi $6,7 \mathrm{mg} / \mathrm{dL}$ menjadi $5,1 \mathrm{mg} / \mathrm{dL}$ dengan persentase penurunan $30,13 \%$. Kadar asam urat pada kelompok percobaan ekstrak etanol Sembung (Bulmea balsamifera) dosis $500 \mathrm{mg}$ dengan kadar setelah diinduksi $7,3 \mathrm{mg} / \mathrm{dL}$ menjadi $5,1 \mathrm{mg} / \mathrm{dL}$ dengan persentase penurunan $23,88 \%$.

Tabel 4. Hasil Persentase Penurunan Kadar Asam Urat

\begin{tabular}{lc}
\hline \multicolumn{1}{c}{ Perlakuan } & $\%$ Penurunan \\
\hline Kontrol Negatif & $-6,34 \% \pm 0,31$ \\
Kontrol Positif & $36,23 \% \pm 1,47$ \\
Ekstrak Jombang (500 mg) & $37,14 \% \pm 1,54$ \\
Ekstrak Sintrong (500 mg) & $7,93 \% \pm 0,34$ \\
Ekstrak Tapak Liman (500 mg) & $37 \% \pm 1,45$ \\
Ekstrak Sambung Nyawa (300mg) & $17,46 \% \pm 0,53$ \\
Ekstrak Bandotan (500 mg) & $4,80 \% \pm 0,01$ \\
Ekstrak Tempuyung (500 mg) & $52 \% \pm 0,2$ \\
Ekstrak Daun Dewa (500 mg) & $30,13 \% \pm 1,25$ \\
Ekstrak Sembung (500 mg) & $23,88 \% \pm 1,10$ \\
\hline
\end{tabular}

Persentase penurunan pada kelompok percobaan tidak melebihi persentase kontrol positif atau allopurinol. Berbagai penelitian menunjukkan bahwa senyawa metabolit sekunder yang diduga dapat menurunkan hiperurisemia ialah senyawa flavonoid. Flavonoid telah terbukti memiliki aktivitas tinggi untuk penghambatan terhadap xantin oksidase, dan ditemukan memiliki 
kemampuan untuk menurunkan kadar asam urat dalam serum. Pada penelitian yang dilakukan oleh Shi-Fu MO (2007) bahwa pemberian secara oral terhadap beberapa senyawa golongan flavonoid yakni quercetin, morin, myricetin, kaempferol, apigenin dan puerarin pada 50 dan $100 \mathrm{mg} / \mathrm{kg}$ selama 3 hari mampu menimbulkan aksi hipourisemia pada tikus hiperurisemia yang diinduksi oleh kalium oksonat. Luteolin, formonoetin dan naringenin menunjukkan efek yang signifikan hanya pada $100 \mathrm{mg} / \mathrm{kg}$. Quercetin, puerarin, myricetin, morin dan kaempferol secara signifikan mengurangi kadar asam urat hati pada hewan hiperurisemia. Selain itu, quercetin, morin, myricetin, kaempferol dan puerarin menunjukkan penghambatan yang signifikan pada aktivitas xanthine oxidase (XOD) hati. (11)

\section{Kesimpulan}

Berdasarkan hasil uji antihperurisemia yang dilakukan, dimana kelompok perlakuan yang memberikan efek antihiperurisemia paling tinggi dalam menurunkan kadar asam urat darah hewan uji mencit yaitu pada kelompok percobaan ekstrak etanol Tempuyung (Sonchus arvensis) pada dosis $500 \mathrm{mg} / \mathrm{KgBB}$ dengan persentase penurunan sebesar $52 \% \pm 0,2$. Sedangkan penurunan paling kecil dalam menurunkan kadar asam urat darah hewan uji mencit, jika dibandingan dengan semua kelompok percobaan dalam penelitian ini yaitu pada kelompok percobaan ekstrak etanol Bandotan (Ageratum coyzoides) pada dosis $500 \mathrm{mg} / \mathrm{KgBB}$ dengan persentase penurunan sebesar $4,80 \% \pm$ 0,01 .

\section{Daftar Pustaka}

1. Wells, B.G., DiPiro, J.T., Schinghammer, T.L., DiPiro, C.V. 2015. Pharmaceutical Handbook. Ninth Edition. McGraw-Hill Education, 1

2. Li Q, Li X, Wang J, et al. 2019. Diagnosis and treatment for hyperuricemia and gout: a systematic review of clinical practice guidelines and consensus statements. BMJ Open ;9:e026677.

3. Nugroho, A., Jae Sue Choi, S.J., Park, H.J. 2016. Analysis of Flavonoid Composition of Korean Herbs in the Family of Compositae and their Utilization for Health. Natural Product Sciences 22(1) : 1-12

4. Rolnik A. and Olas B., 2021. The Plants of the Asteraceae Family as Agents in the Protection of Human Health Int. J. Mol. Sci., 22, 3009

5. Achika, J.I., Arthur, D.E., Gerald, I., Adedayo, A., 2014. A Review on the Phytoconstituents and Related Medicinal Properties of Plants in the Asteraceae Family. IOSR Journal of Applied Chemistry (IOSR-JAC).Volume 7, Issue 8 Ver. I. PP 01-08

6. Omar B., Mohamed N., Rashidah A., Rahim R.A., Wahab H.A., Natural Flavonoids for the treatment of Hyperuricemia, Molecular Docking studies IFMBE Proceedings, 2006, volume 14, pp 178-182

7. Kristiani, R. D., \& Dan Subarnas, D. 2013. Aktivitas Antihiperurisemia Ekstrak Etanol Akar Pakis Tangkur (Polypodium feei) pada Mencit Jantan. BionaturaJurnal IImu-ilmu Hayati dan Fisik 15(3), 156-159. 
8. Cendrianti, F., Muslichah, S., \& Ulfa, E. U. 2013. Uji Aktivitas Antihiperurisemia Ekstrak n-Heksana, Etil Asetat, dan Etanol $70 \%$ Daun Tempuyung ( Sonchus arvensis L .) pada Mencit Jantan Hiperurisemia. Artikel IImiah Hasil Penelitian Mahasiswa, 2(2), 3-7.

9. Nijveldt, R.J. et al. 2001. Flavonoids: a review of probable mechanisms of action and potential applications. Am J Clin Nutr,74:418-25.

10. Sonia, R., Yusnelti, Y. and Fitrianingsih, F. 2020. Efektivitas Ekstrak Etanol Daun Durian (Durio zibethinus (Linn.)) sebagai Antihiperurisemia, Jurnal Kefarmasian Indonesia, 10(2), pp. 130-139. doi: 10.22435/jki.v10i2.2148.

11. Shi-Fu MO et al. 2007. Hypouricemic Action of Selected Flavonoids in Mice: Structure-Activity Relationships. Biol. Pharm. Bull. 30(8) 1551-1556 